\title{
Integration Functions of Topic Chains in Chinese Discourse
}

\author{
Kun SUN \\ University of Tuebingen, Germany \\ Zhejiang University, China \\ kun.sun@uni-tuebingen.de; sharpksun@hotmail.com
}

\begin{abstract}
Topic chain, one of the essential organization devices in Chinese discourse, is highlighted by the use of many co-referential zero forms. Although topic chain plays an important role in organizing discourse, few attempts have been made to explore how topic chain forms an integrated and meaningful unit, and how it facilitates discourse organization through the so-called "integration functions". This study, based on a comprehensive review of topic chain studies, re-examines the core characteristics of the topic chain. Later on, integration functions of the topic chain are analysed at internal and external levels. Topic chain itself can manage its internally different clauses to form a cohesive, meaningful and unified unit. At this stage, this paper clearly demonstrates why so much information within a topic chain assembles in a compact structure. At the discourse level, one topic chain can associate with another topic chains or non-chain constructions to establish textual coherence. Making the use of zero anaphora, co-reference, cognitive orders, and other non-morph-syntactic devices, topic chain can combine different discourse units together to construct Chinese discourse. The study provides a systematic and well-developed account of the integration functions for the Chinese topic chain, which plays a significant role in understanding the nature of a topic chain as well as in understanding on how discourse coherence establishes in Chinese.
\end{abstract}

Keywords: co-referential topic; connection of clauses; unified unit; textual coherence; compactness; meronymy

\section{Povzetek}

Tematsko verigo, eno izmed osnovnih organizacijskih sredstev v kitajskem diskurzu, zaznamuje uporaba številnih soreferenčnih ničelnih oblik. Navkljub dejstvu, da tematska veriga igra pomembno vlogo pri organizaciji kitajskega diskurza, je le malo raziskav na temo, kako le-ta oblikuje celostno in smiselno enoto ter kako pripomore k lažji organizaciji diskurza preko t.i. itegracijskih funkcij. Študija, ki temelji na celovitem pregledu raziskav o tematskih verigah, ponovno preverja glavne značilnosti tematske verige. Hkrati analizira integracijske funkcija na zunanjih in notranjih ravneh verige. Tematska veriga lahko upravlja

Acta Linguistica Asiatica, 9(1), 2019.

ISSN: 2232-3317, http://revije.ff.uni-lj.si/ala/

DOI: 10.4312/ala.9.1.29-57 
s stavki, ki so notranje različni, in iz njih oblikuje oblikuje smiselno povezano, celostno enoto. $\checkmark$ tem delu študija jasno prikaže, zakaj se tako veliko informacij zbere v kompaktni strukturi. Na nivoju diskurza se ena tematska veriga poveže z drugo tematsko verigo ali kakšno drugo strukturo in tako se vzpostavi besedilna skladnost. Z uporabo ničelne anafore, soreferenčnosti, kognitivnega zaporedja in drugih pripomočkov, ki niso morfološki ali sintaktični, je tematska veriga zmožna povezati različne diskurzne enote $v$ kitajski diskurz. Študija ponuja sistematičen in dobro razvit pregled integracijskih funkcij za kitajsko tematsko verigo, kar močno prispeva $\mathrm{k}$ razumevanju narave tematskih verig kot tudi $\mathrm{k}$ razumevanju načina vzpostavljanja diskurzne skladnosti v kitajščini.

Ključne besede: soreferenčna tema; povezava med stavki; poenotena celota; besedilna skladnost; kompaktnost; meronimija

\section{Introduction}

The Chinese language is known as a discourse-oriented language (Tsao, 1979, 1990; Chu, 1998; Li, 2005). Meanwhile, Chinese is regarded as a topic-prominent language (Li \& Thompson, 1976, pp. 457-461). Topic chain is the intersection of the two salient characteristics, as well as the bridge between syntax and discourse. It is characterized by the use of co-referential zero forms in successive different clauses, and is regarded as one of the typical landmark characteristics of the Chinese language.

In comparison with English, topic chain in Chinese is a compact construction stored with large qualities of information, and readers of other languages will wonder why so much information is assembled into a compact and short structure, and how the structure works effectively.

Most studies on topic chains tend to explore how a topic and its co-referential zeros are produced within a topic chain, but ignore how topic chains form a larger propositional meaningful unit or establish textual coherence. An innovative term, "integration function", is used here to specify how a topic chain works to construct small units into a meaningful coherent unification and create textual coherence in Chinese. The term includes two layers, i.e. a topic chain is able to construct its inner unification as an integrated and meaningful unit, and a topic chain can establish textual coherence through cooperating other topic chains or other constructions. Being different from textual coherence, this term "integration function" is characteristic of its form (a structural configuration) and function (coherence establishment) for a topic chain. The purpose of the study is to probe into integration functions of a topic chain from a textual perspective.

The present study first reviews literature on the Chinese topic chain by presenting their linear features. Following this, the paper focuses on integration functions of the topic chain, which is the theme of the study. 


\section{A brief review of studies on Chinese topic chain}

\subsection{Definitions of topic chain}

The term "topic chain" was first put forward by Dixon (1972, p. 71), who investigated an Australian aboriginal language Dyirbal. Tsao (1979) first defined the concept of topic chain in Chinese, which is different from that of Dixon. After him, many linguists worked on Chinese in this field.

Tsao (1979, p. vii) gives his definition of a topic chain for Chinese as, "a topic chain, a stretch of actual discourse composed of one -and often more than one - clause, headed by a topic which serves as a common link among all clauses, that actually functions as a discourse unit in Chinese". He gives an example: (Tsao, 1979, p. 38)

（1）那 棵树, 花 小 $\varnothing$ 叶子 大, $\varnothing$ 很 难 看, nà kē shù huā xiǎo $\varnothing$ yèzi dà $\varnothing$ hěn nán kàn That $M$ tree flower small, (tree) leaves big, (tree) very plain looking, 所以我没买。 suǒy̌̌ $\varnothing \quad$ wǒ méi mǎi so (tree) I NOT buy.

According to Tsao, a topic chain can occur in a simple sentence, where he defines two types: a simple-sentence topic chain and a complex-sentence topic chain. Tsao's definition has been accepted and cited by Li (1985, p. 138), Shi (1992, p. 15), and Li (1995, p. 32).

Li \& Thompson (1981, p. 659) define a topic chain as follows.

One common situation in which noun phrases are unspecified is the topic chain, where a referent is referred to it in the first clause, and then there follow several more clauses talking about the same referent but not overtly mentioning that referent."

Chu (1998, p. 324) offers a more inclusive definition stating that "a topic chain is a set of clauses linked by a topic in the form of ZA (zero anaphora)". His typical example is shown as (Chu, 1998, p. 335):

(2) 一天, 趁

他洗澡, 我边去 检查

yì tiān, $\varnothing$ chèn tā xízăo, wǒ biàn qù jiănchá

One-day, (I) take-advantage-of he bathe, I at-once go search

他的衣服, 翻 上衣的每个袋,

tā de yīfu, $\varnothing$ fān le shàngyī de měi gè kǒudai,

his DE clothes, (I) turn-over- PFV top-clothes' DE every-M pocket, 


$\begin{array}{lll}\text { 又 } & \text { 去 翻 } & \text { 裤子 的 口袋。 } \\ \text { yòu qù fān } & \text { kùzi de kǒudai }\end{array}$

further go turn-over slack DE pocket

Chu's definition is strikingly similar to Li and Thompson's, but he introduces another term, the so-called "zero anaphora", which had not been explicitly mentioned before.

Although Li (2005) does not present a clear definition, her underlying assumption about a topic chain is basically in accordance with Chu's, where zero anaphora is regarded as the core characteristic. Further, $\mathrm{Li}(2005, \mathrm{p} .56)$ holds that the overt topic of a topic chain does not have to occur in the initial clause of a chain, and that some zero NPs can be linked to an overt topic not in the immediate sentence, but in the previous sentence or even previous paragraph, instead. Therefore, Li suggests more forms of a topic chain, such as multi-sentence topic chain; multi-paragraph topic chain; discontinuous topic chain; modifier topic chain.

These definitions all implicitly agree that each clause in a topic chain shares the same topic, but as for the performance requirements of these topics, they display substantial differences. Tsao has no description for the performance of a topic in each clause, while Li and Thompson (1981), Chu (1998) and Li (2005) all are in favor of using zero forms within a topic chain. However, they differ slightly from each other: Li and Thompson think that the overt topic should be located in the initial-sentence position; Chu believes that the topic does not have to appear in the initial position. The clause (the topic clause) with the topic mentioned firstly often occurs at the beginning of the topic chain, but it also possibly occurs in middle of or at the end of the chain (Li, 2004).

By comparison, Li has a more inclusive analysis of zero form performance in a topic chain, and summarizes three features of this phenomenon (Li, 2005, pp. 54-55):

a) a topic is overtly mentioned in the first clause;

b) a topic is anaphorically referred to by a zero form in the subsequent clause(s); and

c) a topic chain is basically a sentence.

What is a topic chain? Generally, the nature of a topic chain can be explored from several aspects such as including its grammatical category, behaviour and function, just to name a few. The perspective of its category is one such aspect. So far, most studies have failed to explicitly delineate its category of a topic chain except for Shi (1989), who considered a topic chain as a syntactic category. Despite of the implicit descriptions, most studies basically agree that a topic chain is a discourse category though it can play an important role in syntax. The discussions on the definitions of the topic chain in previous studies show that making of a topic chain needs the same topic and zero forms, but there nevertheless remain some problems that no previous study seems to deal with. Is a topic chain a unified and meaningful unit, or just a loosely structured discourse? If it is an integrated unit, how do its inner components work together? 
With regards to functions of a topic chain, studies agree that a topic chain is an important device in organizing Chinese discourse, but they have seldom demonstrated how topic chains help build up discourse coherence in detail.

\subsection{Behaviour of the co-referential topic within a topic chain}

The format of the topic chain can be roughly shown as in the diagram below: a shared topic ( $T$ ) is followed by a series of different comment constituents ( $C 1, C 2, C n)$, and a co-referential zero form with a topic is situated in the initial position of each comment clause. Each comment constituent and invisible zero form can be considered to be a clause within a topic chain, such as $\varnothing \mathrm{C} 2$, and $\varnothing \mathrm{Cn}$, and is therefore called a comment clause. T-C1 is called a topic clause.

$$
T--C_{1} \ldots . .(\varnothing) C_{2} \ldots \ldots(\varnothing) C_{3} \ldots . .(\varnothing) C_{n}
$$

There raises a question on whether a visible co-referential form in the position of $\mathrm{C} 2, \mathrm{C} 3$ or $\mathrm{Cn}$ symbolizes that the topic chain will come to the end.

Actually, a topic chain is strung by a topic clause and several comment clauses sharing a co-referential topic, and zero forms within a topic chain are maintained by a co-reference. Co-reference is a topic mechanism which controls each comment clause, so it is assumed that a topic can work to delete each co-referential topic in a clause. In this way, zero forms can be considered to be the result of a deletion run by topic. Therefore, zero forms should not be regarded as the only criteria to judge the boundary of a topic chain. Instead, a co-referential topic is the underlying criteria which should be used to determine the boundary of a topic chain. In most cases, a co-referential topic occurs as a zero form, however, it can also occur visibly (pronominal or nominal forms).

These previous studies show that the following two qualities can constitute a topic chain: zero anaphors and an overt topic (occurring once or invisible). It is important to note that on the surface, the two qualities are able to constitute a topic chain, but besides this, there exist two hidden qualities which ensure the build-up of a topic chain: a co-referential topic and zero forms co-referential with a topic. The co-referential topic is the underlying mechanism to control zero forms instead of zero forms themselves.

Table 1: The possible qualities of a topic chain

\begin{tabular}{ccc}
\hline \multicolumn{2}{c|}{ underlying } & \multicolumn{2}{c}{ superficial } \\
\hline $\begin{array}{ccc}\text { the co-referential zero forms co-referential } \\
\text { topic }\end{array}$ & $\begin{array}{c}\text { zero } \\
\text { with the topic }\end{array}$ & $\begin{array}{c}\text { an overt topic (occurring } \\
\text { once or invisible)? }\end{array}$ \\
\hline
\end{tabular}

Li and Thompson (1981), Chu (1998) insist that the referent (co-referential with a topic) should not overtly be mentioned, and an overt form co-referential with the topic will only occur once, or not occur at all, but they have different ideas whether the overt 
topic should be located in the initial-sentence position. In term of their descriptions, a topic chain is tolerant of an overt topic, indicating that the occurrence of an over topic has no impact on a topic chain which is propped by the underlying qualities (a coreferential topic and zero forms co-referential with a topic). Suppose an overt topic or its co-referential form occurs twice or more in a cluster of clauses, the two underlying qualities are maintained in a cluster of clauses. In other words, when zero forms coreferential with the topic prevail in the cluster in spite of the occurrence of two or more overt topics, all qualities do not violate essential qualities of a topic chain, which carries an over topic or no topic at all. The case of two overt topics is identical with the situation where an overt topic occurs. If an overt topic is seen as one part of a topic chain, two (or more) overt topics are equally treated as parts of a topic chain under the condition of zero forms co-referential with a topic being maintained. However, there is an extreme case where all co-referential topics are not manifested by zero forms, and the cluster of clauses in this case is not seen as a topic chain because the frequent occurrence of overt topics results in no zero forms, completely damaging one underlying quality of making a topic chain.

So we claim that when the occurrence of overt topics has no impact on underlying qualities, the cluster is still treated as a topic chain. Since the occurrence of an overt topic has no direct relation with the underlying qualities, it cannot be treated a necessary quality in making a topic chain despite of the fact that an overt topic often occurs in it once. In such a sense, the requirement of an overt topic just occurring once is neither rational nor justified. When an overt form co-referential with the topic occurs twice or more with zero forms co-referential with the topic being prevalent in a cluster of clauses, the cluster is still a topic chain. Table 2 is a hierarchy of these qualities where " $>$ " indicates that the previous is more important than the latter.

Table 2: A hierarchy of the qualities for a topic chain

$\begin{gathered}\text { the } \\ \begin{array}{c}\text { co-referential } \\ \text { topic }\end{array}\end{gathered} \quad \begin{gathered}\text { zero forms(anaphors) } \\ \text { co-referential with the topic }\end{gathered}>\begin{gathered}\text { zero } \\ \text { anaphors }\end{gathered}>\begin{gathered}\text { an overt topic } \\ \text { (visible or invisible) }\end{gathered}$

It is concluded that the clause where the overt co-referential forms with a topic occur should be considered as one part of a topic chain. A topic chain in a real context can be shown as the following diagram:

$T--C_{1} \ldots \ldots\left(\varnothing / T^{\prime}\right) C_{2} \ldots . .(\varnothing) C_{3} \ldots . .(\varnothing) C_{n}$

' $\varnothing / T$ ' signifies that zero form, or overt co-referential form, can occur in this position. Compared to the first diagram, this diagram shows that the clause, containing an overt form co-referential with a topic, can be seen as a part of a topic chain. 


\section{Integration functions of a topic chain}

Two clauses in English are combined through two different means: subordination and coordination. Sentences or clauses are coherently integrated through different cohesion devices, such as reference, ellipsis, lexical conjunction (Halliday \& Hasan, 1976). Also, more connective devices, as specified by Quirk et al. (1985, pp. 1437-1487), which are more elaborate than those given by Halliday and Hasan, such as pragmatic and semantic implications, intonation, punctuation, and information processing, were identified.

Having special faculties, a topic chain in Chinese can work to connect small units into discourse by making use of their own mechanisms. A topic chain in Chinese performs its integration functions interiorly and exteriorly: firstly, a topic chain itself can manage its different internal clauses to form a cohesive, meaningful and unified unit, without relying on many grammatical devices or markings. Secondly, at the discourse level, one topic chain can cooperate with other topic chains or non-chain constructions to establish textual coherence. Sections 3.1 and 3.2 will discuss its inner and external functions, for which the term "integration function" is used in this study, separately.

\subsection{The inner unification of a topic chain}

A topic chain is considered to have a topic followed by several comment clauses, as shown in the diagram $T--C_{1} \ldots . .(\varnothing) C_{2} \ldots . . .(\varnothing) C_{3} \ldots . .\left(\varnothing / T^{\prime}\right) C_{n}$. Within a topic chain, a topic has the power to control and manage its comment clauses, and meanwhile comment clauses are linked coherently, dependent on some mechanism.

\subsubsection{Topic's control on comment clauses}

Firstly, a topic can control each comment clause through its co-referential mechanism. It is assumed that the topic can work to delete each co-referential topic in a clause. In this way, zero forms can be considered to the result from a deletion performed by the topic, so its co-referential form is encoded as a zero form.

Secondly, a topic chain permits other syntactic constructions to enter, and the inserted construction (embedment) exerts almost no influence on the topic's effective control of its subsequent comment clauses, as illustrated below.

(3) [i] (a) 他 却 带 少年 喜事 得来 的 脚 疯痛, [...]
tā què dài shàonián xǐshì délái de jiǎo fēngtòng,
he yet bring youngster happy-event attain MOD feet pain,

$\begin{array}{lllll}\text { (b) 买了 一 条 六桨 白 木 } & \text { 船, } \\ \varnothing \text { măi le yì tiáo liù jiǎng bái mù }\end{array}$

(he) buy PFV a M six-oared white wooden boat, 
(c) 租 给一个穷 船 主, [......]

$\varnothing$ zū gěi yí gè qióng chuán zhǔ,

(he) rent give a $M$ poor boat

(d) 气运 好,

$\varnothing \quad$ qì yùn hăo

(He) luck good

[ii] (e) [半年 之内 船 不 坏 事],

[bàn nián zhī nèi chuán bú huì shì]

[half year in boat NOT bad thing](embedding element),

[iii] (f) 于是 他从 所赚 的 钱 上, yūshì tā cóng suǒ zhuàn de qián shàng so he from earned MOD money up,

（g）又 讨了一个略有产业的 $\varnothing$ yòu tăo le yí gè lüè yǒu chănyè de (he) again marry PFV a $M$ fairly well-to-do MOD

$\begin{array}{llll}\text { 白脸 } & \text { 黑发 } & \text { 小寡妇。 } & \text { (沈从文《边城》) } \\ \text { bái liăn } & \text { hēi fà } & \text { xiǎo guăfù } & \\ \text { white-face } & \text { black-haired young widow. } & \end{array}$

[Translation] He went home, though with bad feet. He bought a simple six-man wooden boat with his modest savings and rented it out to a boat captain ... Luck was with him; the boat sailed safely, and in six months he'd saved money enough to marry a pretty, black-haired young widow. (Shen Congwen Border Town)

It is noted that several clauses led by the subject "he" are presented (omitted in the ellipsis [......] due to too many clauses in the original version). The embedment in part [ii], "bàn nián zhī nèi chuán bú huì shì", does not interfere with the control of its consequent comment clauses from the topic "tã (he)". Although inserted by other constructions, this topic chain is still very cohesive and unified.

Thirdly, as for some topic chains, a topic has two means of dominating each comment clause. For example,

（4） (a) 德国 全境 受到了野蛮 战争 的 洗劫, déguó quánjìng shòudào le yěmán zhànzhēng de xijjié, Germany whole land suffer to PFV savage fighting MOD loot,

(b)

市㢆萧条,

$\varnothing \quad$ shìchán xiāotiáo,

(Germany) town devastated, 
(c) 田野 荒芜，

(Germany) land desolated,

(d)

$\begin{array}{lll}\varnothing & \text { 生灵 } \text { 涂炭, } \\ \varnothing & \text { shēnglíng tútàn, } \\ \text { (Germany) people plunge into misery, }\end{array}$

(e) 十室九空。

$\varnothing \quad$ shí shì jiǔ kōng

(Germany) ten houses nine empty

[Translation] In the savage fighting, Germany itself was laid waste, the towns and countryside were devastated and ravished, the people decimated.

Example (4) is conducted by the topic "Déguó" (Germany). Each clause in the chain is identified as a double-nominative construction when a zero form is recovered as the first NP. For example, the real form of " $\varnothing$ shìchán xiāotiáo" is "Déguó NP1shìchán NP2 xiāotiáo". Within such a construction, a co-referential zero form usually occupies the initial position of each clause. Consequently, a zero form and the initial nominative entity form a double-nominative construction in each clause of the topic chain. As a common structure, double-nominative construction (DNC) often occurs in Chinese, which has been explored considerably (Shi, 2000; Chen, 2004; Sun, 2018). Its general pattern of a DNC is NP1, NP2 and a predicate following. Therefore, the topic "Germany" has a relation with "town", "land", "people" etc., in this way, when NP1 in each clause is omitted. The topic forms a whole-part, class-member, or possessor-possesee lexical semantic relation with NP2 in each clause and NP2 in each clause can be called a subtopic.

Zero forms ahead of each sub-topic have a topic as their shared referential antecedent, which can well control each of its clause. Besides, a topic and its sub-topics have a meronymous ${ }^{1}$ relation, both at the semantic-lexical level and the textual level, just as analysed in (4). The topic "Déguó" (Germany) has a meronymy relation with those items "shì chán, tián yě, shēng líng" in semantics, i.e. Germany encompasses town, land, people and ten houses, as its components. Therefore, the lexical-semantic connection and co-reference, conducted by the topic, together make this topic chain significantly unified and cohesive.

1 We use "meronymy" to refer to part-whole relations. It is a kind of lexical relation studied carefully by Cruse (1986, pp. 157-180), and it was also analyzed as a lexical cohesion device in text firstly by Hasan (1984). Winston et al. (1987) propose six different types of meronymic relation: componentintegral object, member-collection, portion-mass, stuff-object, feature-activity, and place-area. In Chinese discourse, meronymy is not only a kind of lexical cohesion device, but a device for connecting different clauses with the help of zero forms. 
An English example is given to show a meronym in a discourse, "The car will not move. The engine is broken". Unlike English, a topic chain in Chinese uses different ways to combine its clauses, and as illustrated in Example (4), it prefers to use successive short parallel constructions (often four-character structure) containing subordinate words (town, land, people), which forms meronymous relationship with the superordinate word (Germany). Such a way of using a meronym in a topic chain can not be found in English or other languages (Lassalle \& Denis, 2011).

\subsubsection{The connection of comment clauses}

Comment clauses within a topic chain are not arranged randomly; they are closely related in terms of one of the following three principles: cognitive orders, conjunction linking, and parallelism (or pian-ou construction).

Cognitive sequence, mainly embodied by the temporal consequence principle and spatial conceptual principle, is one general principle for Chinese to obey with respect to clause-clause and sentence-sentence combination. Tai (1985) explores the word order within a clause (sentence), proposing the Principle of temporal sequence (PTS), "The relative word order between syntactic units is determined by the temporal order of the states they present in the conceptual world". Tai's discussion is also applicable to the order of comment clauses within a topic chain. As shown in (5), comment clauses led by the topic "Xiao Zhang', a series of actions, are arranged in order of their occurrence in the physical world.

(5)
(a) 小张
昨天
出门没带伞,
xiăo zhāng $_{1}$ zuótiān chū mén méi dài săn,
Xiao Zhang yesterday walk out NOT carry umbrella,
(b)

$\begin{array}{lll}\emptyset_{1} & \text { 淋 } & \text { 到 雨 了, } \\ \text { (XiaoZhang) } & \text { exposed to rain PFV, }\end{array}$
(c)

$\begin{array}{ll}\text { 受 } & \text { 风 寒, } \\ \emptyset_{1} & \text { shòu le fēng hán, } \\ \text { (XiaoZhang) affect PFV wind chill, }\end{array}$
(d)
发烧 躺在床上不能动了,
$\emptyset_{1}$ fāshāo tăng zài chuáng shàng bù néng dòng le
(XiaoZhang) fever lie on bed up NOT can move PTCP
(e) 也 该打个电话请假啊！
$\emptyset_{1}$ yě gāi dă ge diànhuà qǐngjià a
(XiaoZhang) also should make a phone call ask for a leave MOD

[Translation] Without carrying any umbrella yesterday, Xiao Zhang was affected with chill after being exposed to the rain. Consequently, he could not move lying on the bed with a fever. In spite of this, he still should call to ask for a leave. 
The comment clauses are stated according to the temporal order of event occurrence in Chinese. Their English translations, however, need not follow the original order due to many grammatical devices, such as conjunctions, relativization, etc., with which events are arranged flexibly in English.

Tai (1980) also mentions that, at the syntactic level, "Chinese tends to place the whole before the part, but English tends to do the reverse", and he holds "the wholepart relation is part of our (Chinese) perceptual system and is also a language universal principle". The general "whole-part" principle is quite easy to observe from Chinese word order, but how does the principle of whole-part relation effectively fulfil its function in the topic chain? Different from English, Chinese has few grammatical devices to implement the word order principle. As another cognitive sequence principle, the whole-part relation is supported by a lexical device to ensure that the type of a topic chain presented in (4) maintains orderly, meaningful and cohesive forms.

Developing an English paragraph by space is to arrange things according to their order of location and their relationship to each other. In a spatial sequence, information is arranged on the basis of geography or location, such as from east to west, from north to south, and so on. Take the description of digestion system, for example. In describing how we digest food, we begin with the mouth and work our way down the food pipe to the stomach and then to the intestine, and so on. The spatial sequence is commonly used to develop English paragraph, and it is also effective to arrange the order of comment clauses within the topic chain in Chinese. Temporal sequence and spatial sequence, as usual, are frequently used as cognitive order principles to organize Chinese sentences and discourse. Consider Example (6):

(6) (a) 中午 我 在 没有 导游 陪伴 的 时候
zhōngwǔ wǒ zài méi yǒu dăo yóu péi bàn de shíhou
Noon, I at not have tour guide accompany de time
独自 漫步 街头,
dúzì mànbù jiētóu,
alone stroll street corner

(b) 在中央大道附近发现了一个 $\varnothing$ zài zhōngyāng dàdào fùjìn fāxiàn le yí gè (I) at Central Avenue nearby find PFV a $M$
很大 的棚户区,
hěn dà de pénghùqū,
very large de concentration of huts

(c) 很多茅棚里还住了人。

hěn duō máopéng lì hái zhù le rén.

many huts in still live PFV persons. 
[Translation] Strolling unescorted at midday past a major concentration of the huts just a block from the city's Central Avenue I none the less saw many signs of occupation.

After "Central Avenue" precedes "a major concentration of huts", the locations described just follow the order of "observing", which is in accordance with the spatial order for Chinese readers/hearers, so all these geographical locations should be presented according to the logic order of "observing".

The relationship between comment clauses with zero forms is implicit. Consider the relationship among (a), (b), (c) and (d) in (5) by referring to its English translation. The clauses (a), (b) and (c) lead to the result "Xiaozhang could not move with a fever". The relationship among the first three clauses have been identified to be progressive cause-effect, that is, clause (1) directly causes clause (b), and clause (b) establish the cause of Xiaozhang's chill. Additionally, the four clauses are presented according to the temporal sequence. The following diagram shows implicit relationship among the four clauses in (5). No implicit conjunctions, connectives or other linking words can be found among the four comment clauses, but the topic chain can make the implicit relationship work out to tie with each clause closely.

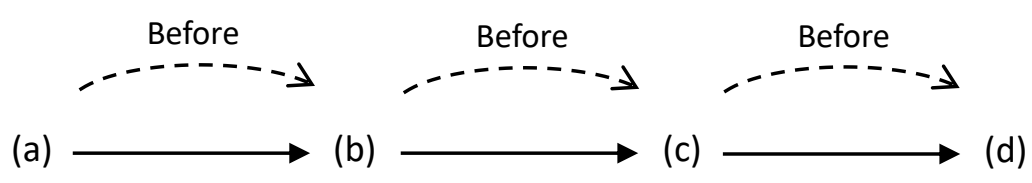

Chinese tends to use quite a few conjunctions or connectives (or other linking devices) between clauses, in comparison with English which uses explicit conjunctions or connectives to join clauses. This tendency often occurs in a topic chain. The comment clauses within a topic chain are arrayed in their logical order in a physical world. Therefore, when we say that Chinese uses few conjunctions/connectives, the tendency is more appropriate for describing order of comment clauses within a topic chain. Sometimes semantic relationships between clauses are left implicit, so interpretations may sometimes require considerable creativity on Chinese speakers/readers. Take (5) as an example. There seems to be a missing link between clause (d) and clause (e), so Chinese natives probably predict that the missing link is about the fact that "Xiaozhang didn't go to work but failed to ask for a leave". The implicit semantic relationships between clauses often occur in a topic chain.

For complex actions and events, the cognitive order is sometimes difficult to perceive. In such cases, overt conjunctions or other linking words should be precisely inserted to indicate the complex relations. Normally, the reverse relation and other anti-cognitive relations should be specifically signified by the use of conjunctions, 
shown as "què" (but) in (7). Observably, such conjunctions have a great influence on the topic expression forms (co-referential zero, pronominal) within a topic chain.

(7) (a) 五魁 仰头 往山看, wǔkuí 1 yăngtóu wăng shān shàng kàn, Wukui raise head to hill top look,
看不到峁梁
$\emptyset_{1} \quad$ kàn bú dào măo liáng
(Wukui) cannot see ridge

(b) 却 想

$\emptyset_{1} \quad$ què xiăng

(Wukui) but think,

(c) 若 立即踏 桥 过 河, 山峁上必是

ruò Lìjí tà qiáo guò hé shān măo shàng bìshì

if Immediately step on bridge cross river, knoll up surely

$\begin{array}{ll}\text { 能 看得见 } & \text { 的 了 } \\ \text { néng kàn de jiàn } & \text { de le } \\ \text { can be able to watch clearly } & \text { DE PFV, }\end{array}$

(d) 就用嘴 呶呶左侧的一处鹰嘴

$\emptyset_{1} \quad$ jiù yòng zuǐ náonáo zuǒcè de yí chù yīng zuǐ

(Wukui) MA Use mouth purse left side DE one $M$ eagle beak

窝 岩,

wō yán

wall rock

(e)

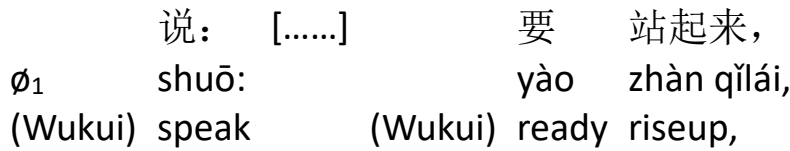

(f)

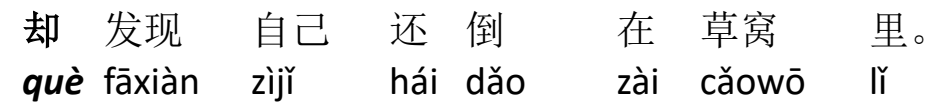

$\emptyset_{1}$ què fāxiàn zijì hái dăo zài căowō lî

(Wukui) but find out himself still collapse into straw lair in

[Translation] Wukui lifts his head from the ground and looks up toward the top of the mountain. The ridge is obscured from his view. It occurs to him that if he should cross the bridge now, whoever is up there would be able to see him. He purses his lips and nods toward the left, indicating a cliff that juts out starkly from the wall of rock, like the beak of an eagle. He wants to rise, but finds himself collapsing into the straw lair. 
Parallelism (or pian-ou construction) ${ }^{2}$ is a frequently used method to organize Chinese clauses. "A parallel structure is a sequence of identical or near identical elements in the same corresponding positions in consecutive clauses" (Li, 2005, p. 113). Similarly, the device, parallelism or pian-ou, is also efficient to combine comment clauses, for example:
(8) 在 这里, 他 比不上
梪窗里的一个
zài zhèlǐ, tāa bǐ bu shàng chúchuāng lǐ de yí gè
At here, he cannot match up shop window in DE one $M$
仿古花瓶,
fáng gǔ huāpíng
imitation ancient vase

\section{比不上掠身而过 的一 身 紫色 的衣裙,}

$\emptyset_{1}$ bǐ bu shàng lüè shēn ér guò de yì shēn zǐsè de yīqún

(he) cannot match up sweeping by DE one $M$ purple DE skirt

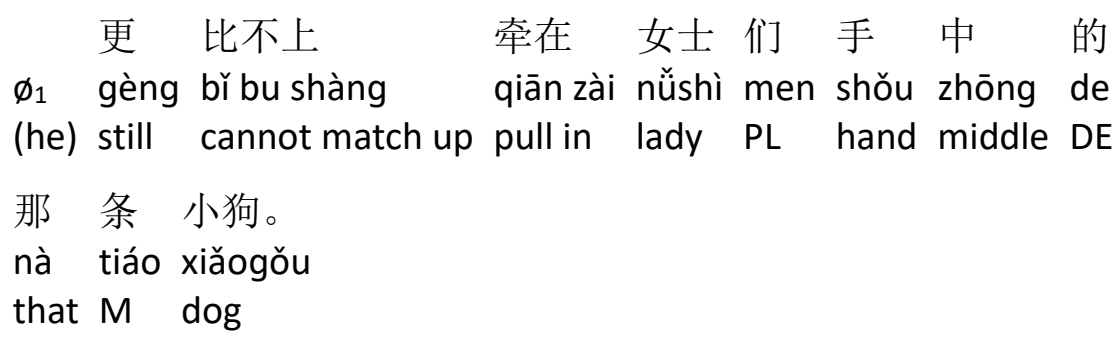

[Translation] Here, he is no match for an imitation of an ancient vase in the shop window, no match for the purple skirt sweeping by, and still no match for the little dog pulled by the hand of a lady.

The three comment clauses make use of the similar construction cannot match up + NP + Preposition + Modifier DE N to create repetition effect; accordingly, the three comment clauses are closely connected, largely by aid of the parallel structure.

Additionally, as four-character structure and parallelism are used properly, the Chinese topic chain will possibly become more readable because the two devices work effectively to strengthen the coherence among comment clauses. Look back at example (4). Comment clauses (b, c, d, and e) are presented by four-character

\footnotetext{
${ }^{2}$ The so-called symmetric sentence is two or two against the move, while the number of words is not required to be equal or symmetrical, and do not require similarly structured sentences. Symmetrical sentences were called pian-ou sentences in ancient China. Actually, pian-ou, similarly to parallel construction, functions as an effective syntactic mechanism to combine different syntactic units in Chinese. pian-ou is also a kind of hypotactic device to strengthen semantic cohesion in Chinese (Pan, 1997, pp. 352-355; Feng, 1997, pp. 133-144). Topic chains make use of the pian-ou device to strengthen combinations.
} 
structure, such as "shìchán xiāotiáo", "tiányě huāngwú", etc., and they have formed a parallel relationship. As a whole, the passage in (4) therefore produces a coherent, powerful and musical effect with repetitious rhyme. However, the two strategies should be used in moderation, and too much abuse will result in undifferentiated effects, not only stale but wearisome.

\subsubsection{The compactness of the topic chain}

As mentioned at the beginning, readers of other languages will wonder why so much information is assembled into a short and compact structure and how the structure works effectively. We know that English will use several sentences and more linguistic devices to express the same amount of information that is stored in a Chinese topic chain with just several short clauses to form a chain-like structure. After so many clauses are compressed into such a compact structure like a narrow passageway, the subject (the topic) in each comment clause will be omitted and sometimes the same constituents adjacent to the subject (the topic) in the former clause will be invisible. Further, interestingly in many cases, Chinese has no need to use linking words in order to clarify temporal and logical relations between the clauses. These omissions may be caused by economic principles of the Chinese language. Due to such economic principles clauses are mostly arrayed according to natural and logical orders. When readers/hearers interpret a topic chain where much information is assembled into this narrow passage, they must heavily rely on their logical orders in physical world (such as PTS, spatial order, cause-effect, etc.) and the co-referential topic to find the implicit relationships, interpret their logical relationships and then understand the information in a topic chain.

In many cases the exact relationship between two clauses may be inferred from several optional logical orders which represent tacit knowledge for native Chinese speakers. However, sometimes the interpretation of implicit relationship needs creativity, inference or cognitive relevance. For example, when a clause (e), follows clause (d) in (5), the topic (Xiao Zhang) is still present in this clause, and therefore clause (e) is still one part of the topic chain though no linking words are used. Consider the relationship between (e) and other clauses. There is no implicit conjunction to indicate it, but readers/hearers are able to infer that (e) bears a concession relationship to the former four clauses. The concession relationship, different from the cause-effect relationship established by the former four comment clauses, is developed through the cognitive relevance to the former cause-effect and reasonable inference. If we use English to express the meaning, some linking word, such as "in spite of", must manifest itself visibly.

As we know, when two English clauses are combined, an explicit linking word will be used to connect them, which makes the order of the two clauses relatively free. Meanwhile it is obligatory for English to indicate which clause is the main clause or 
subordinate clause if these clauses are in subordination, that is, English requires one clause to establish an explicit grammatical and logical relationship with its adjacent one by the use of grammatical devices, such as conjunctions, non-finite verbs etc. By contrast, it is very hard to say which clause is the main clause in a topic chain in many cases, although these clauses bear some semantic relationship by means of their logical orders or reasonable references. Perhaps readers can judge which clause can be considered as the focus of information. Additionally, a Chinese topic chain seems to have an ability to continue only by adding short clauses if speakers want to extend the chain. For example, we can add more comment clauses followed after clause (e) in (5), “(f) Ф (Xiao Zhang) zuì hào huán shì dào yīyuàn qù kàn kàn" (it’s better for him to go to hospital to see the doctor.), “(g) $\varnothing$ (Xiao Zhang) nián jì bù xiào le, $\varnothing$ (Xiao Zhang) zěn me yě bù zhī dào zhàogù zì jǐa!" (He is not young, but why not know how to look after himself). If speakers still want to continue, more relevant comment clauses like (e), (g) can be added. These added clauses are still able to establish a close relationship with the former ones. In such a sense, this is one characteristic of the topic chain.

A topic chain can become a unified, meaningful and integrated construction with the help of a topic control and with close connection of clauses. Chinese tends to assemble amounts of information into very compact structure; in comparison with the Chinese topic chain, English is likely to use several sentences to express and indicate the small unit of subject-predicate by the use of finite verbs, as well as to demonstrate the referents of these zero forms. In such a sense, a topic chain is probably a quite convenient and effective tool to express large quantities of information through simple linguistic codes.

\subsection{The external integration functions in discourse}

Apart from having a powerful internal combination function, topic chains can effectively fulfil the function to construct discourse, through extending externally. In this section, the external integration functions of topic chains will be analysed from two aspects: how a topic chain links to other topic chains to develop discourse; how topic chains make use of non-chain constructions to advance discourse.

\subsubsection{Alliance of topic chains}

In Chinese, several different topic chains can be assembled together to construct discourse; resting on the association of several topic chains, a discourse comes into being. The alliance of topic chains can be viewed in two ways: as a sequence or as a hierarchy. When topic chains are organized as a sequence, this indicates that topic chains will occur in a sequence according to their chronological sequence or spatial order mentioned in 3.1. When topic chains are arranged as a hierarchy, it means that they are integrated into hierarchical whole-part relations. In accordance with their 
linear characteristics and semantic relations, at least four kinds of modes can be summarized.

\section{1) Mode of alternation between topic chains}

A passage is filled with several topic chains, but only led by two topics. One topic and then the other alternate continuously, which often occurs in narrative passages. Consider the following example:

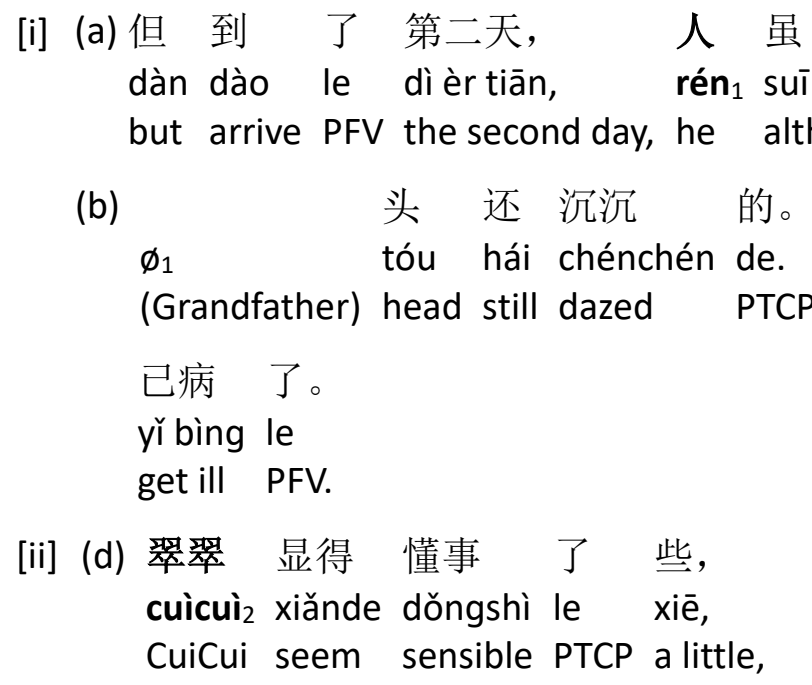

[ii] (d) 翠翠 显得 懂事了些,

cuìcuì 2 xiănde dǒngshì le xiē,

Cuicui seem sensible PTCP a little,

(e) 为祖父煎了一罐大发药,

$\emptyset_{2} \quad$ wéi zǔfù jiān le yí guàn dà fāyào,

(CuiCui) for grandpa concoct PFV a M medicinal herbs,

\begin{tabular}{lllll}
\multicolumn{1}{c}{} & 逼 着 祖父 喝, \\
$\emptyset_{2}$ & bī zhe zǔfù hē, \\
(CuiCui) force & PTCP grandpa drink,
\end{tabular}

(f) 又 在屋后

菜园地

里 摘取 蒜苗

$\emptyset_{2}$ yòu zài wūhòu

càiyuándì

lĩ zhāiqǔ suànmiáo

also behind the house vegetable plot in pluck garlic shoot

泡在 米汤 里作 酸蒜苗。

pào zài mìtāng lĩ zuò suān suànmiáo

soak into rice soup in do sour garlic shoot

(g) 一面

照料 船只,

$\emptyset_{2}$ yímiàn zhàoliào chuánzhǐ at the same time take care boat

(h) 一面 还 时时刻刻 抽空 赶回家 $\emptyset_{2} \quad$ yímiàn hái shíshí kèkè chōukòng gănhuíjiā (CuiCui) at the same time still hourly find time return home 


\author{
里 来 看 祖父, \\ lì lái kàn zǔfù \\ in come see grandpa, \\ (i) \\ 问 这样 那样。 \\ $\emptyset_{2} \quad$ wèn zhèyàng nàyàng \\ (Cuicui) ask this that \\ [iii] (j) 祖父 可 不 说 什么, 只是 为一个 \\ zǔfù ${ }_{1}$ kě bù shuō shénme, $\emptyset_{1} \quad$ zhǐshì wéi yí gè \\ Grandpa yet NOT say anything (Grandpa) only for a M \\ 秘密 痛苦 着。 [.......] \\ mìmì tòngkǔ zhe \\ secret suffer PTCP \\ [iv] (k) 翠翠 看不出祖父 有什么要紧 事情 \\ cuìcuì 2 kàn bu chū zǔfù yǒu shénme yàojǐn shìqíng \\ Cuicui couldn't find out grandfather have what emergent thing \\ 必须当天 进城, \\ bìxū dàngtiān jìnchéng \\ must that very day go into town \\ (I)

$\begin{array}{lll}\emptyset_{2} & \text { 请求 他 莫 去。 (《边城》) } \\ \text { (Cuicui) } & \text { request him not go }\end{array}$

[Translation] Though he (grandfather) gets up next day, his head is still heavy. Cuicui, rising to the occasion, prepares a cooling concoction and makes him take it, after which she picks some garlic behind the house to boil with congee for him. Between trips on the boat, she runs home to see how he is. He says nothing, but his secret preys on his mind. Three days in bed restore him enough to walk about a little; and although his bones still ache, he decides to go into town. Cuicui can not understand what could be so important as to make Grandpa go to town so soon. She begs him not to go. (Shen Congwen, biān chéng)

The passage is composed of several topic chains ([i], [ii], [iii] and [iv]), but is led by just two topics "grandfather" and "CuiCui". The topic chains led by the two topics are switched easily and smoothly without the use of any grammatical marking or conjunction to strengthen the cohesion. The topic chains are arranged in terms of Temporal Sequence, so the way of association is viewed as a sequence mentioned at the beginning of this part; as a result, the discourse woven by two kinds of topic chains is quite natural and fluent. Based on the mode (two or three topics alternate repeatedly), several topic chains are successively connected to construct narrative discourse, which especially occurs in novels. 


\section{2) Mode of meronymous topic chains}

After one topic chain comes to an end, other topics in the successive topic chains have some semantic relations with the topic of the previous topic chain. Semantic relations are expectedly meronymous, expressing either whole-part, class-member, or possessor-possesee relation. For example:

(10) [i] (a) 泸沽湖 是一个天然 内陆 淡水湖,

lúgū hú ${ }_{1}$ shì yí gè tiānrán nèilù dànshuǐ hú

Lugu Lake is a $M$ natural inland freshwater lake

位于滇西北云南与 四川 两 省 交界处,

wèiyūdiān xīběi yúnnán yǔ sìchuān liăng shěng jiāojièchù

locate in NW Yuannan and Sichuan two provinces juncture

[ii] (b) (湖) 面积 50 平方公里,

[ $\varnothing_{1} \quad$ miànjī 50 píngfāng gōnglĭ,

(Lugu lake) area 50 square $\mathrm{kms}$

(c) 海拔 2680 米,

$\emptyset_{1} \quad$ hăibá $2680 \mathrm{mì}$

(Lugu lake) sea level 2680 meters

(d) (湖) 平均水深 45 米。

$\emptyset_{1} \quad$ píngjūn shù shēn 45 mì]

(Lugu lake) average water depth 45 meters,

[iii] (e) 湖中 有八岛十四湾和一个海堤连岛,

húzhōng 2 yǒu bā dăo shísì wān hé yí gè hăidī liándăo lake middle have 8 islands 14 coves and a M sea bank dyke

(f) 小岛棋布星罗;

$\emptyset_{2} \quad$ xiăo dăo qíbù xīngluó

(lake middle) small island spread all over the place

[iv] (g) 湖岸植被 葱郁,

hú'àn ${ }_{3}$ zhíbèi cōngyù,

lake bank plants verdant,

(h)

青山 环绕,

风光旖㻈。

$\emptyset_{3} \quad$ qīngshān huánrào $\emptyset_{3}$ fēngguāng y̌̌nǐ

(lake bank) green hills surround (lake bank) scenery exquisite

[Translation] Lugu Lake is a natural freshwater lake located at the juncture of southwest China's Yunnan and Sichuan Provinces, with an altitude at 2680 meters above sea level and an average depth of 45 meters. It covers an area of 50 square $\mathrm{km}$ in which there are eight islands, 14 coves and a dyke, and small islands 
spreading throughout the lake, with verdant plants thriving on its banks. Surrounded by green hills, the lake shows exquisite scenery.

Part [ii] in Example (10) is assembled by several double nominal constructions, having several co-referential zero forms with the topic "Lugu Lake". Since part [i] is defined as a zero-form topic chain, [i] and [ii] together make a larger topic chain. The same pattern recurs in two other topic chains [iii] and [iv] which have different topics, led by 'hú zhōng' (lake middle) and 'hú àn' (lake bank) respectively. Obviously, entities of the two topics and co-referential zero forms in [iii] and [iv] can be regarded as components of "Lugu Lake", which makes us conclude that the first topic, from the lexical relation perspective, has set up a merynomous relation with the latter two topics. Topic chains are thus organized hierarchically, and compared to the first topic chain conducted by "Lugu Lake", the second (lake middle) and third topic chains (lake bank) appear at lower ranks. .

In this way, topics establish a meronymous relation lexically, with the three different topic chains being integrated into a hierarchical whole-part relation. The example illustrates that different topic chains with meronymy relations can build discourse efficiently.

\section{3) Mode of network form}

Generally, linear characteristics of topic and comment clauses can be described as the topic being the focus, and comment clauses as its radiated items, A traditional zeroform topic chain therefore can be drawn into a radioactive diagram. When several zero form topic chains occur successively, they are woven into a network-shape construction as shown in (11):
(a) 小王
放下
书包，
Xiăo Wáng ${ }_{1}$ fàngxià shūbāo
Xiao Wang put down bag,
(b)
把 [ii] 球 扔过去,
$\emptyset_{1} \quad$ bă qiú 2 rēng guòqù
(Xiao Wang) BA ball throw pass over
(c) 正好砸到窗户,
$\emptyset_{2} \quad$ zhènghăo zádào chuānghu
(ball) just fall to window
(d)（球把）玻璃 打坏了, $\emptyset_{3} \quad$ bōli dăhuài le (ball make) glass broken PFV,




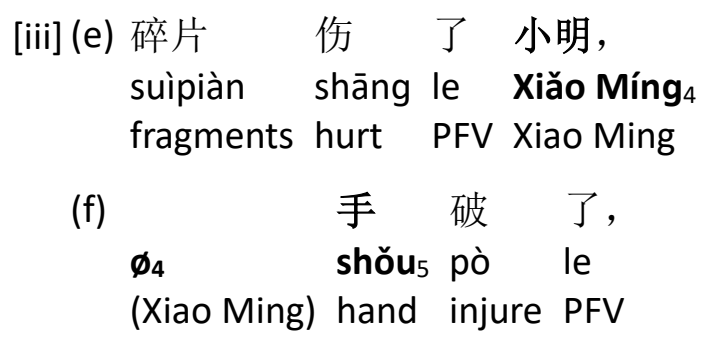
（g）（小明手）流了不少 血, $\emptyset_{5} \quad$ liú le [iv] bù shăo xuè 6 (Xiao Ming hand) lose PFV a lot of blood
(h) 淋 到 衣服上, $\emptyset_{6} \quad$ lín dào yîfu shàng (blood) flow to clothes up
(i)（血把衣服印）红了一大 片, $\emptyset_{6} \quad$ hóng le yí dà piàn (blood) dye red PFV a large piece
(j) 怎么 也 止不住, $\emptyset_{6} \quad$ zěnme yě zhǐbuzhù (blood) anyway also cannot stop
[v] (k)（小明）哇哇大哭起来。 $\emptyset_{4} \quad$ wāwā dà kū qùlái (Xiao Ming) onomatopoeia big cry up

[Translation] After putting down his bag, Xiao Wang threw the ball away, but the ball just hit the window; as a result, the window glass broke into pieces. The broken glass fragments injured Xiao Ming' hands and he lost quite a lot blood. The blood spread into his clothes and largely dyed them red. Anyway, the blood could not be stopped, so Xiao Ming cried loudly.

The example above displays a network formed by several different topic chains. The passage consists of several zero form topic chains, and each topic chain is advanced progressively ([i], [ii], [iii], [iv], [v]). The eight topics are mentioned successively in the passage: Xiao Wang-qiu-chuan wai-sui pian-Xiao Ming-shou-xue-Xiao Ming. The second topic ([ii]) is mentioned in the comment clause in the first topic chain([i]). After the first topic chain terminates, the second topic begins to form its chain. A similar pattern recurs with all further topic chains, and we can say that the previous chain is transited onto the next, and therefore all topic chains together form a network.

Through transiting from one to the next, each topic is related with the next consistently and smoothly. Finally, these topic chains are woven into a complex network, shown in Figure 1: 


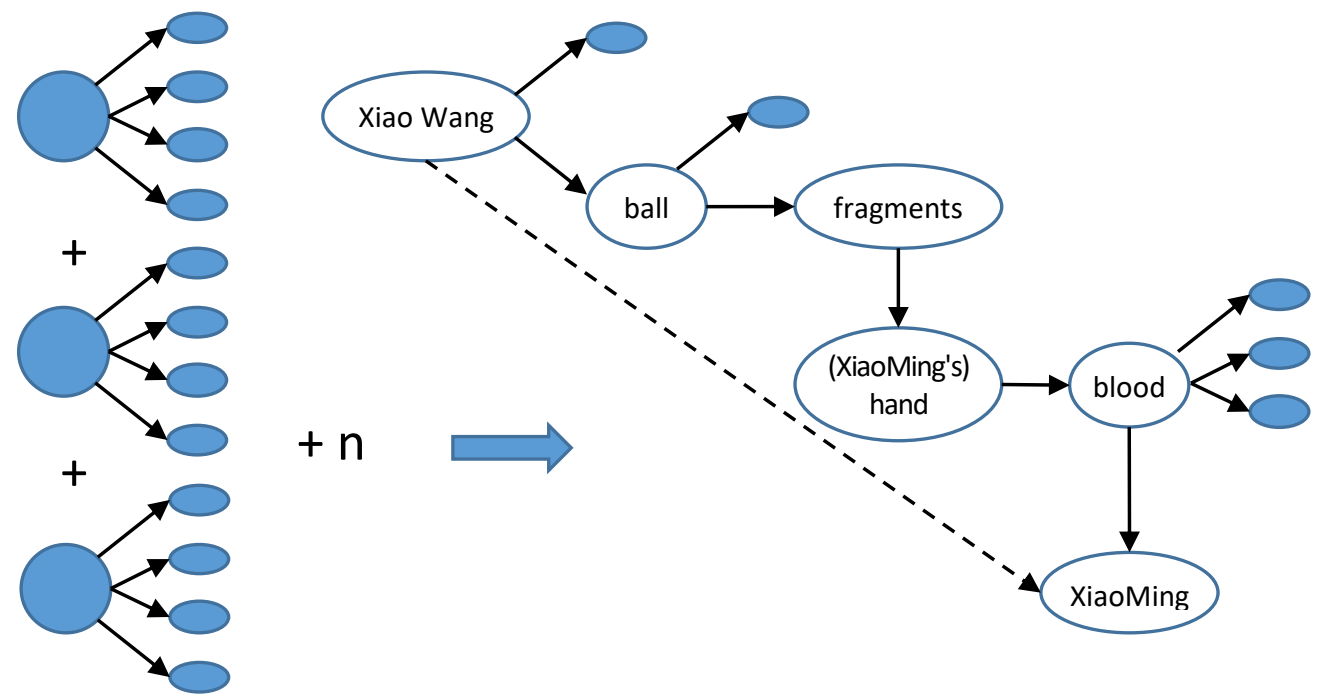

Figure 1: Representation of combination process for Example (11)

In this way one topic chain is associated with the sequential topic chain through the transitional progression; consequently, different topic chains are interwoven into a larger network, but the general order of arrangement for the sequence of topic chains should be in accordance with PTS. The two means ensure that cohesion in the passage is substantially enhanced.

Noticeably, Chu (1998, pp. 330-337) mentions two types of a topic chain: the embedded topic chain and the telescopic topic chain. The embedded topic chain is the performance of one topic chain permitting other structures to enter, which also proves strong domination of the topic over the whole chain. A telescopic topic chain is defined as involving two topic chains merging into each other at the end of one and at the beginning of another chain. Just as a discourse pivot serves as the object of the first verb and the subject of the second verb, it also serves as the last link of one chain and the first link of another. The piece of discourse that consists of two or more topic chains linked in this manner can be called a telescopic topic chain. From Chu's examples, we find that a telescopic topic chain coincides with the network formed by different topic chains through the transited manner. The transited connected manner is more complex than the pivot which serves as the object of the first verb and the subject of the second verb, so a telescopic topic chain is a special case of our network mode. In this way, the mode in the study is more inclusive than the telescopic topic chain.

Additionally, Cheng (1988) proposes a model of topic continuity which You (1998, p. 32) bases on in the following diagram. The model is similar to the mode in this study, showing that this mode of network form is a continuation of Cheng's and Chu's work. 


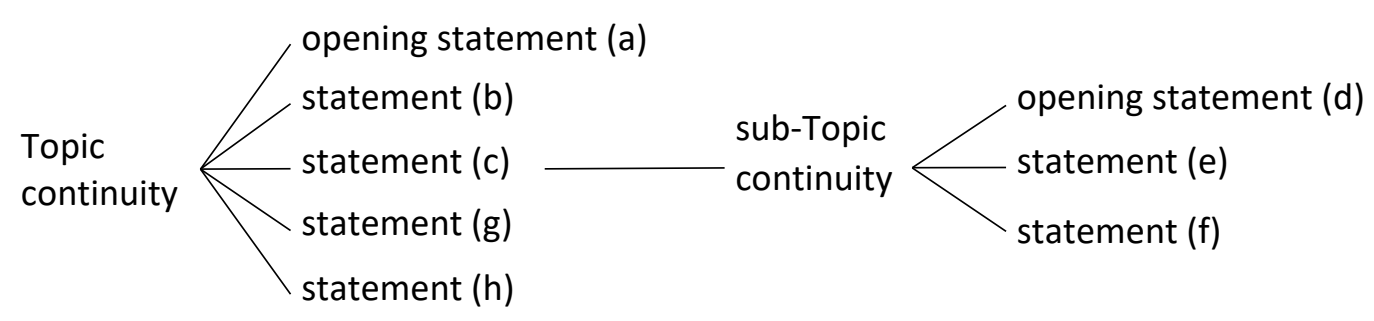

Figure 2: The model of topic continuity (Cheng 1988)

\section{4) Embedding modes of topic chains}

Embedded topic chain (Chu, 1998, p. 330) can be considered as the performance of a topic chain permitting other structures to enter, where the embedded topic chain is regarded as a part of a larger chain. At the same time, an embedded topic chain and its larger topic chain can also be viewed as the two separate topic chains, so the embedded relation can also be defined as a mode of different topic chains establishing discourse. For example,

$$
\begin{aligned}
& \text { (李四这家伙, 我 因为救 他受了伤, }
\end{aligned}
$$

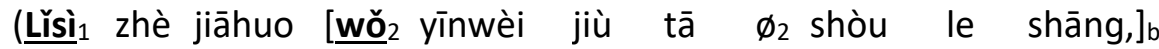

$$
\begin{aligned}
& \text { Lisi this dude I because save him, (I) receive PFV wound, } \\
& \text { 竟然 不 来 看 我, } \\
& \emptyset_{1} \quad \text { jìngrán bù lái kàn wǒ } \\
& \text { (Lisi) even NOT come see me } \\
& \text { 跑到纽约度假去了。 } \\
& \emptyset_{1} \text { păodào Niǔyuē dùjiă qù le.)a } \\
& \text { (Lisi) run-to New York have vacation go PFV }
\end{aligned}
$$

[Translation] Lisi, that dude I was wounded in saving, doesn't even come to see me and went to New York for a vacation.

The topic chain controlled by "wǒ" (I) is embedded within a larger topic chain conducted by "Lisi (a name of a person)". As stated in 3.1, a topic chain is tolerant to being inserted by other syntactic constructions, and the inserted syntactic construction is possibly identified as another topic chain. So the language phenomenon can be described as a large topic chain having a small, different one attached. This is also one method for topic chains to create textual coherence.

Concerning this mode, we should pay special attention to the change in antecedents of zero forms. In Example (12), the first zero form refers to "I", but the second zero has the antecedent of "Lisi", the same as the third zero. The question that arises is how speakers/readers know that the referents of the second and third zero form have been shifted. It is the clause, " $\emptyset_{1}$ jìngrán bù lái kàn wǒ", that provides many 
cues for speakers/readers to know who performs the actions. The predicate "not come to see me", for example, denies that "I" will come to see me, so only "Lisi" will be qualified to take the action. Since "I" was wounded, it is impossible for "me" to go to New York, and thus the third zero must refer to "Lisi". The continuous zero forms having different referring entities can be judged from the clues provided from the context, and are called switch referents (You, 1998; Lee, 2003; Tao, 1996, 2001).

Primarily dependent on the four modes, topic chains take full advantage of lexical semantic linkage and cognitive consequence principles to constitute Chinese discourse. Compared with other languages, it is distinctive of Chinese to construct discourse through the four modes by using few grammatical devices. This has not been found in English (Esser, 2009) or other European languages (Longacre, 2007, pp. 372-420) so far.

\subsubsection{The incorporation of topic chains and non-chain forms}

It is almost impossible for Chinese discourse to be entirely composed of one topic chain alone. Once one topic chain determinates, it is likely to be followed by other topic chains, and sometimes by other constructions. In the realistic context, one topic chain is possibly subsequently connected with other non-chain constructions. Observe the following examples.

(13) (a) 船夫

方面

还 以为上次

歌声既归

(T1) chuánfū ${ }_{1}$ (C1) fāngmiàn hái yǐwéi shàngcì gēshēng jì guī Ferryman (T1) side (C1) still think last time song attribute

二老 唱 的,

èrlăo chàng de

the second sing DE

(b) 在此后几个日子里, 自然还 会听到那种歌声。 zài č̌ hòu jǐ gè rìzi lǐ zìrán hái huì tīngdào nà zhǒng gēshēng In the next few days in, should still can listen to that kind song

(c) 一到了晚间就 故意 从 别样 事情上, yí dào le wănjiān jiù $(\mathrm{C} 2)$ gùyì cóng biéyàng shìqíng shàng arrive PTCP evening MA intentionally from other things up,

(d)

促 翠翠 注意 夜晚 的歌声。

$\emptyset_{1}(\mathrm{C} 3)$ cù cuìcuì zhùyì yèwăn de gēshēng

(ferryman)(C3) urge CuiCui notice evening DE song.

(e) [两人吃完 饭 坐在屋里,

[liăng rén chī wán fàn zuò zài wū lĩ

[Two persons eat PFV dinner sit in the house, 


$\begin{array}{lll}\text { 因 } & \text { 屋前 } \quad \text { 滨水, } \\ \text { yīn } & \text { wū qián } & \text { bīn shuǐ } \\ \text { because } & \text { front near } & \text { water, }\end{array}$

(f)

\begin{tabular}{|c|c|c|c|c|c|}
\hline 脚 & 蚊子 & 一到 & 黄昏 & 就 嗡嗡 & 的 叫着], \\
\hline & & yídào & huánghūn & jiù wēngwēng & de jiào zhe] \\
\hline
\end{tabular}

(g)

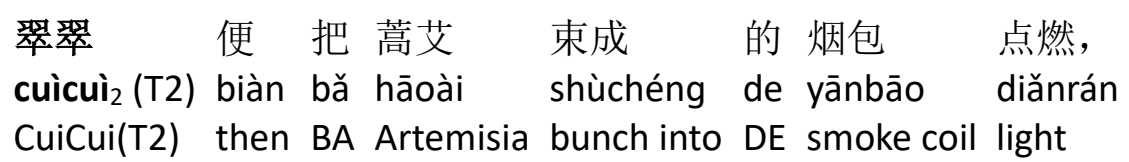

(h)

$\emptyset_{2}(\mathrm{C} 1)$

向屋中角隅 各处

晃 着

(CuiCui) (C1) to house middle corner every place wave PTCP

驱逐 蚊子。

qūzhú wénzi

drive mosquito.

(i)

$\begin{array}{lll}\emptyset_{2}(C 2) & \text { 晃 } & \text { huăng le yízhèn } \\ \text { (CuiCui)(C2) } & \text { wave PFV a while }\end{array}$

[Translation] The ferryman thinks that, since Number Two was the singer, they will hear more of his songs in the next few days. When evening falls, he encourages Emerald to listen for songs that night. After supper they sit indoors. Because their hut stands above a stream, it is filled with the droning of mosquitoes at dusk, and Emerald waves a lighted coil of Artemisia in every corner to drive the mosquitoes away. (Shen Congwen biān chéng)

There are two types of topic chains constructed by "T1 (ferryman)" and "T2 (CuiCui)" respectively in the passage. Nevertheless, other non-chain forms marked in grey in the passage are embedded within the two topic chains, and the embedment (clause e and f) performs the background ${ }^{3}$ to transit from the first chain to the second. Although the non-chain constructions are not directly related to the time of the narrative, which has a clear line of progression formed by topic chains in the passage, the constructions, as the background information, still link the two events stated in the two topic chains.

\footnotetext{
${ }^{3}$ Thompson (1987) and Givón (1987) published a detailed analysis of a background and foreground, but so far the relations of the two terms have not been clearly stated. They state simply, a background is often considered to be the material that represents sidetracks and thus does not have to be in temporal order, generally takes stative verbs, and is usually coded in imperfective aspect. By contrast, a foreground is regarded to be the material that presents the event line of a narrative. (Chu, 1998, p. 219).
} 

(a) 五魁 便 见 天清早 拾 粪, […… wǔ kuí biàn jiàn tiān qīng zăo shí fèn Wukui MA see morning gather animal droppings
(b) 看 着 柳家门前的动静, $\varnothing \quad$ kàn zhe liǔ jiā mén qián de dòng jing (Wukui) look PTCP Liu house gate front DE come and go.
(c) 终一日, 太阳 还没有 出来,
[zhōng yírì tàiyáng hái méiyǒu chūlái One day, sun still NOT come out

(d) 村

村口、 河岸 一层 薄 雾 闪动 着 蓝光。
cūn kǒu, hé àn yì céng báo wù shǎndòng zhe lánguāng.]
village entrance, river bank a layer thin mist waver PTCP blue light

(e) 五魁 焦见 女人 提 着 篮子 到 河边

[wǔ kuí qiáojiàn nŭrén tí zhe lánzi dào hébiān

Wukui see woman carry PTCP basket arrive riverbank

$\begin{array}{lll}\text { 洗 } & \text { 衣服 } & \text { 了。 } \\ \text { xì yifu le] } \\ \text { wash clothes } & \text { PFV. }\end{array}$

(f) 女人 还是 那么 俊俏, (她的) 脸 却 苍白了 许多, nŭrén háishì nàme jùnqiào liăn què cāngbái le xǔduō woman still so pretty, (woman) face but pale PFV very much

（g）挽了袖子将白藕般的胳膊伸进 $\varnothing \quad$ wăn le xiùzi jiāng bái ǒu bān de gēbo shēn jìn (she) roll PFV sleeve JIANG white lotus root like DE arm put into 水里 来回搓摆。(《五魁》) shuǐ lĩ láihuí cuōbǎi water in repeatedly twist

[Translation] He takes up the practice of gathering animal droppings at the crack of dawn.... Or he stands afar on the opposite bank of the river that flows past it, watching the comings and goings. Finally, one day, before the sun has arisen, when the entryway to the village and the river as well are both bathed in a luminous bluish mist, he sees the woman carrying a basket of laundry to the riverbank. She's as pretty and charming as ever, though her face is paler than he remembers. After rolling up her white lotus root-like arms, she puts her arms into water to twist away clothes repeatedly. (wǔ kuí)

The passage consists of two topic chains, (a)-(b) and (f)-(g), and two non-chain constructions, (c)-(d) and (e). The non-chain construction (c)-(d) does not participate 
in the narrative process of the passage as background information, while the non-chain structure (e) manages to connect one topic chain (a)-(b) and the other chain (f)-(g) together through its participation into their shared narrative progression and eventline time. At the moment, non-chain construction (e) works as the foreground information to advance the narrative progression, and strengthen the combinations of two topic chains as well as narrative and non-narrative information.

The functions of non-chain constructions can be summarized as:

1) the non-chain construction is encoded as background information, which is closely relevant with what is discussed in the topic chain, but a non-chain construction does not participate in the narrative process of topic chains, shown as in (13);

2) the non-chain construction also serves to associate one topic chain with the other through its narrative participation and time trace, and sometimes the construction possibly participates in the time process of topic chains, as in (14).

\section{Conclusion}

Clearly, the topic chain in Chinese can construct discourse and help achieve textual coherence. The topic chain in Chinese discourse has its own special mechanism for combining different discourse units into a large textual segments, which is only found in a few languages, particularly in East Asian languages.

The study concentrated on the integration functions of the topic chain in Chinese discourse. To clarify how topic chains integrate smaller units into larger ones in discourse, many efforts have been made to investigate its internal unification and external integration functions in discourse. The study tentatively presented several discourse organizational modes of topic chains, illustrated by many realistic Chinese texts. It carefully and closely examined the integration functions for the topic chain, and is thought to be significant for deeper understanding the nature of topic chain and how discourse coherence is established in Chinese.

\section{References}

Chen, P. (2004). Hanyu shuangxiang mingciju yu huati chenshujiegou 汉语双向名词与话题-陈 述结构 [Double NP constructions and topic-comment articulation in Chinese]. Zhongguo Yuwen 中国语文[Studies of the Chinese Language], 6, 493-507.

Cheng, C-C. (1988). Tongxin benwei hanyu pianzhang yufa 通信本位汉语篇章语法 [Communication-based Chinese discourse grammar]. Shijie Hanyu Jiaoxue 世界汉语教学 [Chinese Teaching in the World], 1, 6-13.

Chu, C-C. (1998). A Discourse Grammar of Mandarin Chinese. New York: Peter Lang. 
Cruse, A. D. (1986). Lexical Semantics. Cambridge: Cambridge University Press.

Dixon, R. M. W. (1972). The Dyirbal Language of North Queensland. Cambridge: Cambridge University Press.

Esser, J. (2009). Introduction to English Text-linguistics. Frankfurt: Peter Lang.

Feng, S. (1997). Hanyu de Yunlü, Cifa yu Jufa 汉语的韵律、词法与句法 [Interactions between Morphology, Syntax and Prosody in Chinese]. Beijing: Peking University Press.

Givón, T. (1987). Beyond foreground and background. In R. Tomlin (Ed.), Coherence and Grounding in Discourse (pp. 173-188). Amsterdam: John Benjamins.

Halliday, M.A.K \& Hasan, R. (1976). Cohesion in English. London: Longman.

Hasan, R. (1984). Coherence and cohesive harmony. In J. Flood (Ed.) Understanding Reading Comprehension (pp. 181-219). Delaware: International Reading Press.

Lassalle, E. \& Denis, P. (2011). Leveraging different meronym discovery methods for bridging resolution in French. In I. Hendrickx, S., Devi, A., Branco \& R., Mitkov (Eds.) Anaphora Processing and Applications (pp. 35-46). Berlin: Springer.

Lee, C-L. (2003). Zero Anaphora in Chinese. Taipei: Crane Publisher.

Li, C. N., \& Thompson, S. A. (1976). Subject and topic: a new typology of language. In C. N, Li. (Ed.) Subject and Topic (pp. 457-61). New York: Academic Press.

Li, C. N., \& Thompson, S. A. (1981). Mandarin Chinese: A Functional Reference Grammar. Berkeley: University of California Press.

Li, I-C. (1985). Participant Anaphora in Mandarin Chinese. PhD dissertation, University of Florida.

Li, H. (1995). Topic Chain Structure in Chinese Conversations. PhD Dissertation, University of Minnesota.

Li, W. (2004). Topic chains in Chinese discourse. Discourse Processes, 37(1), 25-44.

LI, W. (2005). Topic Chains in Chinese: A Discourse Analysis and Applications in Language Teaching. Muenchen: Lincom Europa.

Longacre, R. E. (2007). Sentences as combinations of clauses. In T. Shopen (Ed.) Language Typology and Syntactic Description (2nd edition) Vol.2: Complex Structure (pp. 372-420). Cambridge: Cambridge University Press.

Pan, W. (2007). Hanyingyu Duibi Gangyao 汉英语对比纲要 [The Outline of Contrastive Studies between Chinese and English]. Beijing: Beijing Language and Culture University Press.

Quirk, R., Greenbaum, S., Leech, G., \& Svartvik, J. (1985). A Comprehensive Grammar of the English Language. London: Longman.

Shi, D. (1989). Topic chain as a syntactic category in Chinese. Journal of Chinese Linguistics, 17, 223-262.

Shi, D. (1992). The Nature of Topic Comment Constructions and Topic Chains. PhD dissertation, Southern California University.

Sun, K. (2018). Approaching the double-nominal construction in Mandarin Chinese through the semantic-cognitive interaction. Studia Linguistica, 72(3), 687-724.

Tai, H.Y. (1980). Toward a cognition-based functional grammar of Chinese. In H. Tai \& H. Frank (Eds.), Functionalism and Chinese Grammar no.1 (pp.187-226), Monograph Series of the Journal of the Chinese Language Teachers Association. 
Thompson, A. S. (1987). "Subordination" and narrative event structure. In R. Tomlin (Ed.) Coherence and Grounding in Discourse (pp. 435-454). Amsterdam: John Benjamins.

Tao, L. (1996). Topic discontinuity and zero anaphora in Chinese discourse: cognitive strategies in discourse processing. In B. Fox (Ed.), Studies in Anaphora (pp. 487-513). Amsterdam: John Benjamins.

Tao, L. (2001). Switch reference and zero anaphora: emergent reference in discourse processing. In A. Cienki, B. Luka \& M. Smith (Eds.), Conceptual and Discourse Factors in Linguistic Structure (pp. 253-269). Stanford: CSLI Publications.

Tsao, F-F. (1979). A Functional Study of Topic in Chinese: The First Step Towards Discourse Analysis. Taipei: Student Book Co.

Tsao, F-F. (1990). Sentence and Clause Structure in Chinese: a Functional Perspective. Taipei: Student Book Co.

Winston, M.E., Chaffin. R. \& Herrman, D. 1987. A taxonomy of part-whole relation. Cognitive Science, 11(4), 417-444.

You, Y-L. 1998. Interpreting Chinese Zero Anaphora Within Topic Continuity. PhD dissertation, University of Illinois at Urbana-Champaign.

\section{Abbreviations and symbols}

$\begin{array}{ll}\text { CONJ } & \text { conjunction } \\ \text { DE } & \text { modifier (de) } \\ \text { MSTC } & \text { meronymy style topic chain } \\ \text { M } & \text { measure word } \\ \text { MA } & \text { modality adverbs (jiu, cai, you, hai, etc.) } \\ \text { MOD } & \text { modifier } \\ \varnothing & \text { zero form } \\ \text { PASS } & \text { passive } \\ \text { PROG } & \text { progressive } \\ \text { PFV } & \text { perfective aspect } \\ \text { PTCP } & \text { particle } \\ \text { ZA } & \text { zero anaphor }\end{array}$

\section{Acknowledgments}

This study was funded by the National Social Sciences Foundation of China (Fund No. 15CYY038) and China Postdoctoral Science Foundation (Fund No. 2018T110581). 